\title{
Performance of Partially Replaced Plastic Bottles (PET) as Coarse Aggregate in Producing Green Concrete
}

\author{
Md. Rashedul Haque ${ }^{*},{ }^{,}$Md. Belal Hossain ${ }^{1}$, Md. Roknuzzaman ${ }^{1}$, Noor-A-Afrin Emu ${ }^{2}$, Fatema Tuz Jahan ${ }^{2}$ \\ ${ }^{1}$ Assistant Professor, Hajee Mohammad Danesh Science and Technology University, Bangladesh \\ ${ }^{2}$ Graduate Student, Hajee Mohammad Danesh Science and Technology University, Bangladesh
}

\section{Keywords}

\section{PET,}

Green Concrete, Compressive strength, Workability,

Plastic Fiber.

\begin{abstract}
Disposal of plastic bottles made from Poly-Ethylene Terephthalate (PET) is a worldwide problem. Green concrete, made with one or more recycled items, is also a trendy concept in the sustainable construction sector. The current study is to investigate the possibility of using recycled PET waste bottles as a partial replacement of natural coarse aggregate in green concrete to get marginal effective compressive strength and workability. Two different sizes of PET fiber such as $10 \mathrm{~mm} * 10 \mathrm{~mm}$ and $19 \mathrm{~mm} * 19 \mathrm{~mm}$ are used. Four different replacement percentages such as $0 \%$ (control), $1 \%, 5 \%$, and $10 \%$ of coarse aggregate are adopted with a fixed water-cement ratio of 0.42. A total of 42 cylindrical specimens are prepared and conventional water curing is done for 7 days and 28 days. Compressive strength for control specimen (0\%) after 7 days and 28 days curing is found as $39.96 \mathrm{MPa}$ and $53.42 \mathrm{MPa}$ respectively. On the other hand, the compressive strength of specimens with $10 \mathrm{~mm} * 10 \mathrm{~mm}$ plastic fiber is found to be $22.40 \mathrm{MPa}, 16.14 \mathrm{MPa} \& 11.83 \mathrm{MPa}$ after 7 days curing and $38.48 \mathrm{MPa}, 25.81 \mathrm{MPa} \& 20.08 \mathrm{MPa}$ after 28 days of curing for $1 \%, 5 \%$, and $10 \%$ replacement of coarse aggregate respectively. For $19 \mathrm{~mm} * 19 \mathrm{~mm}$ plastic fibers, these values are $21.22 \mathrm{MPa}, 7.99 \mathrm{MPa} \& 4.29 \mathrm{MPa}$ after 7 days of curing and $35.82 \mathrm{MPa}, 11.36 \mathrm{MPa}$ \& 7.03 MPa after 28 days of curing for the same percentages. The findings of the study may serve as a guideline for deciding the replacement percentage and fiber size for preparing PETbased green concrete.
\end{abstract}

\section{Introduction}

In modern civilization, concrete is the most popular construction material due to its numerous advantages. As per technological advancement for reducing environmental effects, scholars are trying to use several recycled materials as a replacement for one or more natural ingredients in concrete. Such concretes are popularly known as "Green Concrete". Recycled aggregates from demolished structures, rubbers from scrap tires, fly ashes, rice husks, several types of fibers can be used to replace the natural aggregates and binding materials within a certain limit preserving the properties of resulting green concrete. There are Several studies are conducted to justify such modifications. It is reported that green concrete incorporating $7.5 \%$ replacement of coarse aggregate with tire chips may produce concrete with $8.33 \%$ less strength as compared to its control specimen [1]. Successful replacement of coarse aggregate with recycled aggregate to produce green concrete is presented in several studies [2-4]. The use of different types of fiber as partial replacement of aggregate is also investigated by researchers [5-6]. Plastic waste is made of several toxic chemicals and reprehensible for soil, air, and water. As a nonbiodegradable material plastic preserves in the soil for a long time as a harmful substance. The largest component of plastic waste is polyethylene, followed by polypropylene, polyethylene terephthalate and polystyrene. In Dhaka City, the capital of Bangladesh, solid waste typically contains 3 to $5 \%$ plastics consisting mainly polyethylene terephthalate (PET) bottles, polyvinyl chloride (PVC), high density polyethylene (HDPE), low-density polyethylene (LDPE), and polypropylene (PP) [7]. PET is significantly lighter than natural aggregate (NA) and therefore its inclusion lowers the densities of the resulting concrete [8]. Another advantage of using plastic is that the workability of concrete with $75 \%$ plastic concrete improves about $123 \%$ compared to that of the normal concrete in the w/c ratio of 53\% [9] and was lighter (lower density), was more ductile (greater Poisson's ratios and reduced modulus of elasticity), and had lower drying shrinkage and higher resistance to chloride-ion penetration [10].

PET is a polymer of the monomer ethylene terephthalate. The molecular formula of PET is (C1OH8O4) n. which is shown in Figure 1.

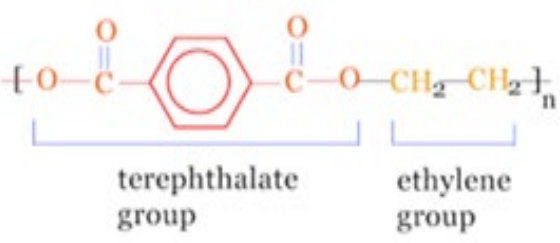

Several investigations were done on the plastic fiber using as a coarse aggregate or fine aggregate. Different proportions or percentages of plastic fiber were given different results on workability, density, compressive strength, tensile strength. A study conducted by replacing 10\%, 20\% \& 30\% coarse aggregate (brick chips) with PET reports a reduced compressive strength for PET aggregate concrete with the increment of PET in concrete compared to the normal aggregate concrete [7]. In another study, using the shredded waste plastic in concrete with partial replacement of $5 \%, 10 \%$, and $20 \%$ by volume of conventional coarse aggregate shows that the strength of concrete containing PET aggregate falls in the category of lightweight concrete in terms of their strength, specific gravity and density [11]. Suitability of plastic coarse aggregate (PCA) for structural concrete is also evaluated and a percentage replacement of $22 \%$ natural coarse aggregate (NCA) with PCA is found to be beneficial [12]. 
Analyzing the earlier studies, it is found that there is more scope to work in this sector. The influence of plastic size on two key parameters of green concrete such as strength and workability are taken into consideration for the present study. The study outcomes are expected to bring some economic as well as environmental benefits.

\section{Materials and methods}

\subsection{Materials}

Different types of materials are used for carrying out for different research work. For making the plastic coarse aggregate (PCA) concrete, sand as fine aggregate, crushed stone as coarse aggregate, cement as a binder, plastic bottles of two sizes as a replacement of coarse aggregate, and potable water are used. All the materials were collected from local sources in Dinajpur District, Bangladesh. The properties of the materials were obtained by following the American Society for Testing and Materials (ASTM) standards [13-18]. Two different sizes of plastic fibers are used and they are obtained by cutting plastic bottles and giving the proper size. The sizes of fibers are $10 \mathrm{~mm} * 10 \mathrm{~mm}$ and $19 \mathrm{~mm} * 19 \mathrm{~mm}$. The properties of the materials are given in Table 1.

Table 1. Material Properties

\begin{tabular}{ll}
\hline Materials & Properties \\
\hline \multirow{2}{*}{$\begin{array}{l}\text { Coarse Aggregate } \\
\text { (Stone Chips) }\end{array}$} & Specific Gravity: 2.66; Water \\
& Absorption: 0.334\%; Maximum \\
& size: 25 mm; Gradation: \\
& Conforming ASTM C33 [17] \\
\hline Fine Aggregates & Specific Gravity: 2.33; Water \\
(Sand) & Absorption: 2.67\%; Fineness \\
& Modulus: 2.60 \\
\hline & Brand: Premier Cement \\
Binding Materials & (Manufactured \\
(Ordinary Portland Cement) & in Bangladesh) \\
Type: CEM-I (52.5N) & Specific Gravity: 3.15; Normal \\
& Consistency: 26\% \\
& Setting times: Initial-85 min, \\
& Final- 205 min \\
\hline \multirow{2}{*}{ Plastic fiber } & Specific Gravity: 1.29; Water \\
& Absorption: 0.02\% \\
\hline Water & Potable water \\
\hline
\end{tabular}

\subsection{Descriptions of the mix arrays}

Plastic fibers are used as a replacement of coarse aggregate and water cement ratio was kept constant as 0.42 . Keeping all other factors identical, only two size of plastic fiber was used at different percentages. Mixes with different percentage and size of plastic fiber is designated as shown in Table 2.

Table 2. Designation of mix arrays

\begin{tabular}{|c|c|}
\hline Designation & Description \\
\hline $\mathrm{A}$ & $0 \%$ of $\mathrm{PET}$ \\
\hline B & $\begin{array}{l}10 \mathrm{~mm} * 10 \mathrm{~mm} \text { size of plastic fiber } 1 \% \text { of } \\
\text { coarse aggregate volume }\end{array}$ \\
\hline C & $\begin{array}{l}10 \mathrm{~mm} * 10 \mathrm{~mm} \text { size of plastic fiber } 5 \% \text { of } \\
\text { coarse aggregate volume }\end{array}$ \\
\hline $\mathrm{D}$ & $\begin{array}{l}10 \mathrm{~mm} * 10 \mathrm{~mm} \text { size of plastic fiber } 10 \% \text { of } \\
\text { coarse aggregate volume }\end{array}$ \\
\hline $\mathrm{E}$ & $\begin{array}{l}19 \mathrm{~mm} * 19 \mathrm{~mm} \text { size of plastic fiber } 1 \% \text { of } \\
\text { coarse aggregate volume }\end{array}$ \\
\hline$F$ & $\begin{array}{c}19 \mathrm{~mm} * 19 \mathrm{~mm} \text { size of plastic fiber } 5 \% \text { of } \\
\text { coarse aggregate volume }\end{array}$ \\
\hline G & $\begin{array}{c}19 \mathrm{~mm} * 19 \mathrm{~mm} \text { size of plastic fiber } 10 \% \text { of } \\
\text { coarse aggregate volume }\end{array}$ \\
\hline
\end{tabular}

\subsection{Mix proportioning}

Mix proportioning is done following American Concrete Institute (ACI) practice ACI-211.1-91 [19]. Based on design criteria of C35 concrete, all the ingredients are calculated as presented in Table 3.

\begin{tabular}{|c|c|c|c|c|}
\hline \multirow{3}{*}{$\begin{array}{c}\text { Mix } \\
\text { Materials } \\
\text { Water/Cement ratio }\end{array}$} & \multicolumn{4}{|c|}{$\begin{array}{c}\text { Percentage of PET } \\
\left(10 \mathrm{~mm}{ }^{*} 10 \mathrm{~mm} \& 19 \mathrm{~mm} * 19 \mathrm{~mm}\right)\end{array}$} \\
\hline & $0 \%$ & $1 \%$ & $5 \%$ & $10 \%$ \\
\hline & \multicolumn{4}{|c|}{0.42} \\
\hline Cement $\left(\mathrm{kg} / \mathrm{m}^{3}\right)$ & 488 & 488 & 488 & 488 \\
\hline \multicolumn{4}{|l|}{ Coarse Aggregate $\left(\mathrm{kg} / \mathrm{m}^{3}\right)$} & 821 \\
\hline $\begin{array}{l}\text { Fine Aggregate } \\
\left(\mathrm{kg} / \mathrm{m}^{3}\right)\end{array}$ & 676 & 676 & 676 & 676 \\
\hline Plastic fibers $\left(\mathrm{kg} / \mathrm{m}^{3}\right)$ & 0 & 10 & 46 & 91 \\
\hline
\end{tabular}

\subsection{Preparation of specimen}

Cylindrical specimens are prepared and its size is $100 \mathrm{~mm}$ in diameter and $200 \mathrm{~mm}$ high. All the materials are mixed properly to produce normal and PCA concrete specimens according to ASTM standard procedures [19]. 42 cylindrical specimens were prepared and cured them for 7 days and 28 days according to ASTM guideline [20].

\subsection{Testing of specimens}

Slump test to measure workability of mix is conducted during the mixing process according to ASTM standards [21] and the slump values are recorded for each mix array during. Compressive strength tests are conducted after 7 days and 28 days of curing following the standard procedure as described in ASTM C39/C39M-12 [22].

\section{Results}

\subsection{Influence on workability}

Workability is the property determining the effort required to manipulate a freshly mixed quantity of concrete with minimum loss of homogeneity [23]. Slump value is considered an indirect measurement of workability. The slump test results for PCA concrete mix and control mix are shown in Figure 2 and Figure 3.

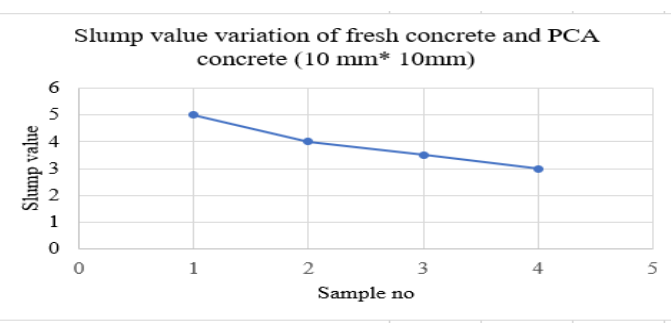

Figure 2. Slump value variation between fresh concrete and PCA concrete using different percentage (1\%,5\%,10\%) of $10 \mathrm{~mm} * 10 \mathrm{~mm}$ size plastic fibers

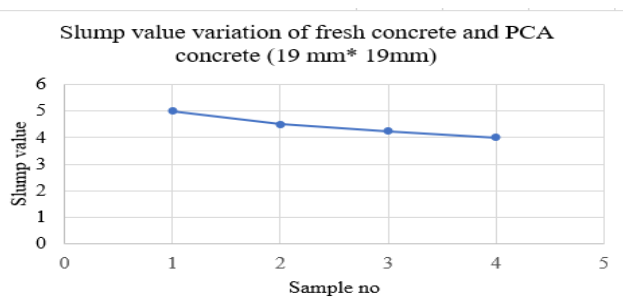

Figure 3. Slump value variation between fresh concrete and PCA concrete using different percentage (1\%, 5\%,10\%) of $19 \mathrm{~mm}$ * $19 \mathrm{~mm}$ size plastic fibers 
The slump value is found to decreased with increasing the percentage of plastic fiber. Mixes with $19 \mathrm{~mm} * 19 \mathrm{~mm}$ size of plastic fibers show better workability than $10 \mathrm{~mm} * 10 \mathrm{~mm}$ size because the absorption capacity of plastic is very low. So, larger size of particles has limit absorption capacity than smaller size. Similar observation of lower workability with smaller plastic additive is reported in literature [24].

\subsection{Influence on compressive strength}

\subsubsection{Compressive strength after 7 days}

After the curing process of 7 days, the compressive strength of control specimen is found $39.96 \mathrm{MPa}$. The corresponding strength value of PCA concrete specimens using two size plastic fibers at different percentage was lower than fresh concrete. Figure 4 and Figure 5 illustrates the results.

Compressive strength(Mpa) for 7 days $(10 \mathrm{~mm} * 10 \mathrm{~mm})$

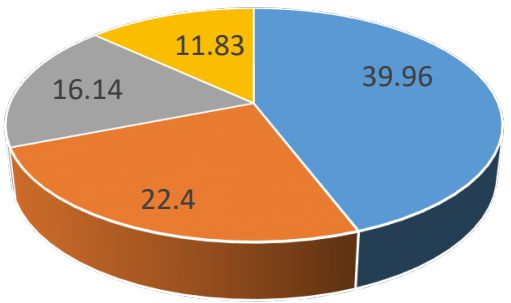

- A (0\%) PET - B (1\%) PET - C (5\%) PET - D (10\%) PET

Figure 4. compressive strength for 7 days between normal concrete and PCA concrete by using $10 \mathrm{~mm}$ * $10 \mathrm{~mm}$ plastic fibers (A, B, C \& D stands for $0,1,5 \& 10 \%$ replacement of coarse aggregate respectively)

Compressive strength(Mpa) for 7 days $(19 \mathrm{~mm} * 19 \mathrm{~mm})$

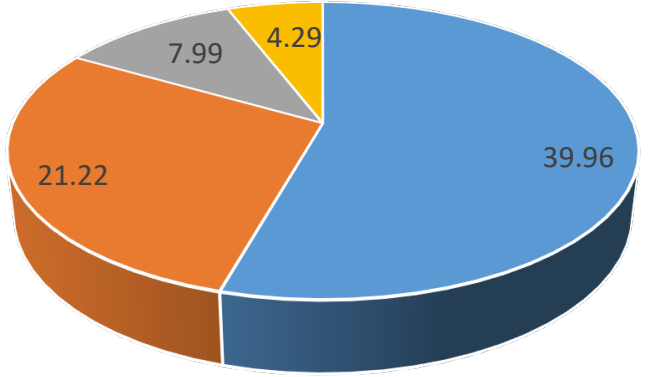

- A (0\%) PET - E (1\%) PET = F (5\%) PET $\because \mathrm{G}(10 \%) \mathrm{PET}$

Figure 5. compressive strength for 7 days between normal concrete and PCA concrete by using $19 \mathrm{~mm}$ * $19 \mathrm{~mm}$ plastic fibers (A, E, F \& G stands for 0, 1, 5 \& 10\% replacement of coarse aggregate respectively)

The PCA concrete using $19 \mathrm{~mm}$ * $19 \mathrm{~mm}$ plastic fibers are found to give lower compressive strength than PCA concrete using $10 \mathrm{~mm} * 10 \mathrm{~mm}$ plastic fibers. The variation is shown in Figure 6.

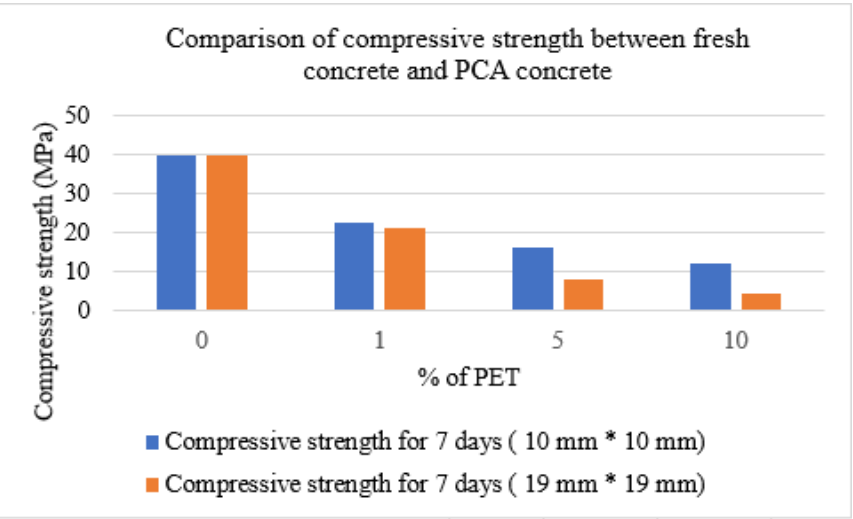

Figure 6. Compressive strength variation between fresh concrete and PCA concrete using two sizes plastic fibers 7 days

It is clear from Fig. 6 that early strength gaining is much better in the cases of smaller sized PET fiber modified concrete.

\subsubsection{Compressive Strength Test for 28 days}

After the curing process of 28 days, the compressive strength of control specimen is found $53.42 \mathrm{MPa}$. The corresponding values of compressive strength for PCA concrete specimens are presented in Figure 7 and Figure 8.

\section{Compressive strength(Mpa) for 28 days} $(10 \mathrm{~mm} * 10 \mathrm{~mm})$

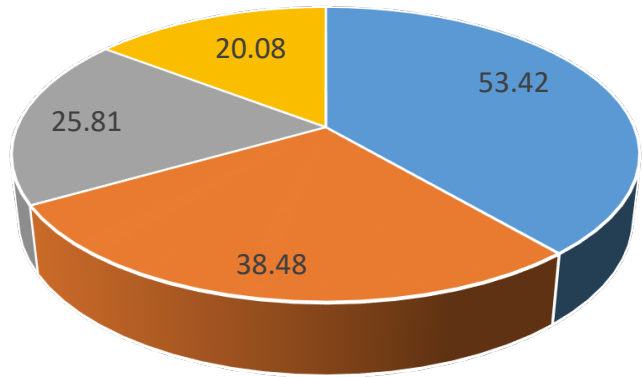

- $\mathrm{A}(0 \%) \mathrm{PET}$ - $\mathrm{B}(1 \%) \mathrm{PET} \quad \mathrm{C}(5 \%) \mathrm{PET} \quad \mathrm{D}(10 \%) \mathrm{PET}$

Figure 7. compressive strength for 28 days between normal concrete and PCA concrete by using $10 \mathrm{~mm}$ * $10 \mathrm{~mm}$ plastic fibers (A, B, C \& D stands for 0,1, 5 \& 10\% replacement of coarse aggregate respectively) 
Compressive strength(Mpa) for 28 days $(19 \mathrm{~mm} * 19 \mathrm{~mm})$

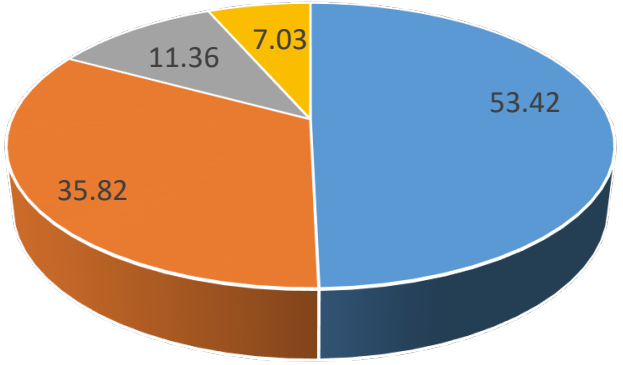

- $\mathrm{A}(0 \%) \mathrm{PET}$ - E (1\%) PET - F (5\%) PET $-\mathrm{G}(10 \%) \mathrm{PET}$

Figure 8. compressive strength for 28 days between normal concrete and PCA concrete by using $19 \mathrm{~mm}$ * $19 \mathrm{~mm}$ plastic fibers (A, E, F \& G stands for $0,1,5 \& 10 \%$ replacement of coarse aggregate respectively)

It is noticed that the PCA concrete using $19 \mathrm{~mm}$ * $19 \mathrm{~mm}$ plastic fibers was given lower compressive strength than PCA concrete using $10 \mathrm{~mm}$ * $10 \mathrm{~mm}$ plastic fibers. The variation of compressive strength is presented in Figure 9.

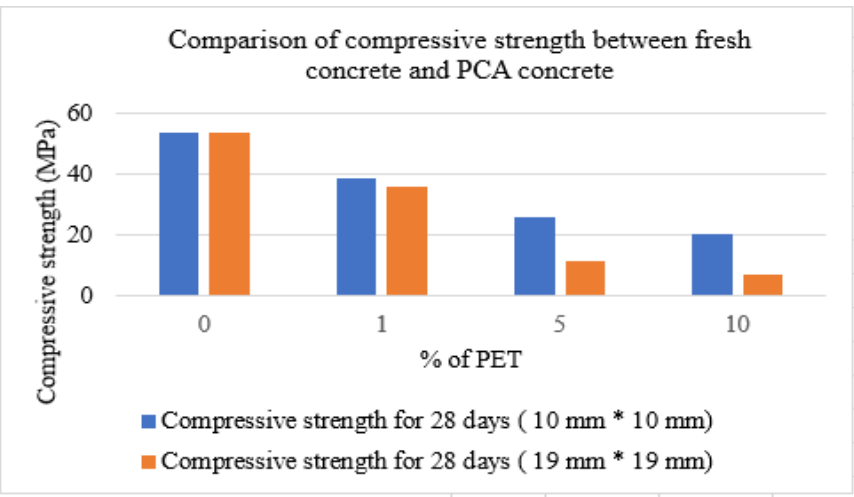

Figure 9. Compressive strength variation between fresh concrete and PCA concrete using two sizes plastic fibers for 28 days

The compressive strength up to $25 \mathrm{MPa}$ is used for reinforced concrete structure and foundation and lower compressive strength may be used for non-structural construction and minimum loading structure. In this study, target compressive strength is $35 \mathrm{MPa}$ and observed compressive strengths of PCA concrete with $10 \mathrm{~mm}$ * $10 \mathrm{~mm}$ plastic fibers are found to be $38.48 \mathrm{MPa}, 25.81 \mathrm{MPA}$ and $20.08 \mathrm{MPa}$ for $1 \%, 5 \%$ and $10 \%$ replacement, respectively. $1 \%$ replacement fairly exceeds the target strength for $\mathrm{C} 35$ concrete. $5 \%$ and $10 \%$ replacement downgrade them to $\mathrm{C} 25$ and $\mathrm{C} 20$ concretes, respectively. The strength loss is more severe in the cases of $19 \mathrm{~mm}$ * $19 \mathrm{~mm}$ PET fibers. Here, $1 \%$ replacement yields a compressive strength of $35.82 \mathrm{MPa}$ which is very close to requirement of $\mathrm{C} 35$ concrete. But $5 \%$ and $10 \%$ replacement make the concrete very weak with a minimal compressive strength of only 11.36 and $7.03 \mathrm{MPa}$.

\subsection{Influence on unit weight}

The average unit weight variation among the control concrete and PCA concrete are shown in the Table 4.

Table 4. Unit weight of different concrete specimens

\begin{tabular}{lllll}
\hline $\begin{array}{l}\text { Sample } \\
\text { designation }\end{array}$ & $\begin{array}{l}\text { PET } \\
\text { PET }\end{array}$ & $\begin{array}{l}\text { Size of plastic } \\
\text { fibers }\end{array}$ & $\begin{array}{l}\text { Unit } \\
\text { weight } \\
\left(\mathrm{kgm}^{-3}\right)\end{array}$ & $\begin{array}{l}\text { Weight } \\
\text { loss (\%) }\end{array}$ \\
\hline A & - & & 2841 & - \\
B & 1 & $10 \mathrm{~mm}^{*} 10$ & 2746 & 3.34 \\
C & 5 & $\mathrm{~mm}$ & 2742 & 3.48 \\
D & 10 & & 2628 & 7.50 \\
E & 1 & & 2730 & 3.91 \\
F & 5 & $19 \mathrm{~mm} * 19$ & 2721 & 4.22 \\
G & 10 & $\mathrm{~mm}$ & 2625 & 7.60 \\
\hline
\end{tabular}

A fair weight reduction upto $7.6 \%$ as compared to the control mix is encountered.

\subsection{Mode of failure}

The mode of failure of fresh concrete and PCA concrete by using two size of plastic fibers are found to be different. During the tests, the control concrete cylinders exhibits an explosive and sudden failure. But, the failure of PCA using two types of plastic fibers are more gradual and ductile. The failure modes of control concrete and PCA concrete are shown in Figure 10.
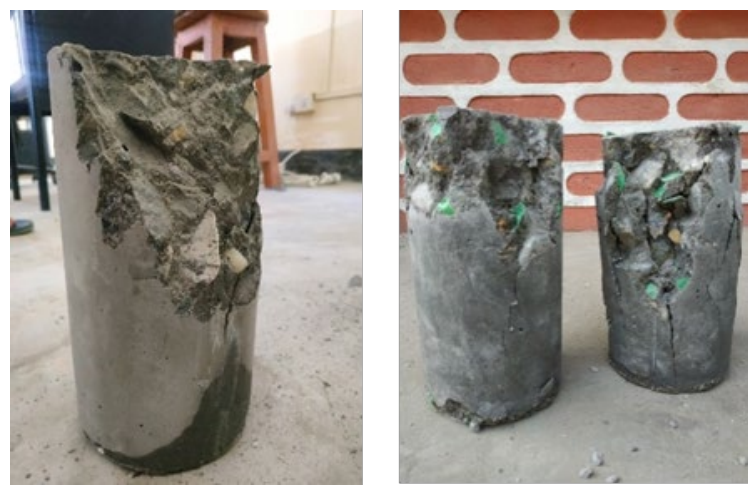

Figure 10. Failure mode of concrete (a)Fresh concrete (b) PCA concrete

\section{Conclusion}

In this research work different percentage of plastic (1\%, 5\%, 10\%) was used to produce environment friendly green concrete. Destructive test was conducted to know the strength variation. The study findings may be concluded as,

$>$ The workability of control mix is greater than that of PCA concrete mix. It decreases with the usage of different types of fiber. The reduction of workability of concrete is less in larger sized fiber (19mm).

$>$ Addition of fiber helps to reduce the unit weight of concrete which is advantageous in reducing self-weight of structures. The largest size plastic fiber $(19 \mathrm{~mm})$ with maximum percentage $(10 \%)$ had lowest unit weight as compared to others.

$>\quad$ As the different sizes of plastic fibers were used to produce concrete, the strength variation is noticed. More strength has been found in small size plastic fiber for making PCA concrete. 
$>$ From the destructive test of concrete, it is found that $1 \% \mathrm{PCA}$ replacement of coarse aggregate can achieve the designated target compressive strength of $\mathrm{C} 35$ concrete for both sizes.

$>$ The smaller size plastic fiber $(10 \mathrm{~mm})$ used in PCA with $5 \%$ replacement of coarse aggregate can also be used for construction purposes.

$>\quad$ Mode of failure of control concrete and PCA concrete is found to be different. Control concrete gave sudden cone failure but PCA concretes are found to show gradual and ductile failure.

A recommendation is therefore made to use smaller-sized plastic fibers, as replacement of coarse aggregate to get the best result. This study concentrates on compressive strength and workability of PCA based green concrete. It is recommended to conduct extensive studies for evaluating flexural performance, durability performance, and shear performance in order to judge the ultimate potential of PET fiber as an ingredient of green concrete.

\section{Declaration of Conflict of Interests}

The authors declare that there is no conflict of interest. They have no known competing financial interests or personal relationships that could have appeared to influence the work reported in this paper.

\section{References}

[1.] Roknuzzaman, M., Hossain, M.B., Sultana, A. and Shourov, A.A. Influence of tire chip size on the behavior of rubberized concrete, Civil Engineering Beyond Limits, 3 (2021), 18-22. https://doi.org/10.36937/cebel.2021.003.004

[2.] Revilla-Cuesta, Víctor, Marta Skaf, Flora Faleschini, Juan Manue Manso, and Vanesa Ortega-López. "Self-compacting concrete manufactured with recycled concrete aggregate: An overview." Journal of Cleaner Production 262 (2020): 121362

[3.] Sivakrishna, A., Adeyemi Adesina, P. O. Awoyera, and K. Rajesh Kumar. "Green concrete: A review of recent developments." Materials Today: Proceedings 27 (2020): 54-58.

[4.] Iqbal, Muhammad Farjad, Qing-feng Liu, Iftikhar Azim, Xingyi Zhu, Jian Yang, Muhammad Faisal Javed, and Momina Rauf. "Prediction of mechanical properties of green concrete incorporating waste foundry sand based on gene expression programming." Journal of hazardous materials 384 (2020): 121322.

[5.] Abbass, W., Khan, M. I., \& Mourad, S. Evaluation of mechanical properties of steel fiber reinforced concrete with different strengths of concrete. Construction and building materials, 168 (2018), 556-569.

[6.] Islam, M. S., \& Ahmed, S. J. Influence of jute fiber on concrete properties. Construction and Building Materials, 189 (2018), 768776

[7.] Md. Jahidul Islam, Iftekhar Alam Dipta and Md.Rahat, Investigation of recycling poly-ethylene terephthalate (PET) as partial replacement of coarse aggregate in concrete, Journal of Civil Engineering (IEB), 46 (1) (2018) 11-20.

[8.] Nabajyoti Saikia, Jorje de, Brito, Waste Polyethylene Terephthalate as an Aggregate in Concrete, Materials Research. 2013; 16(2): 341-350.

[9.] Yun-wang choi, Dae-Joong moon, Jee-Seung chung, Sun Kye cho, Effects of waste PET bottles aggregate on the properties of concrete, Cement and Concrete Research 35 (2005) 776 - 781.

[10.] S.C. Kou, G. Lee, C.S. Poon, W.L. Lai. Properties of lightweight aggregate concrete prepared with PVC granules derived from scraped PVC pipes, Waste Management, 29 (2),(2009), 621-628.
[11.] Hossain, M., Bhowmik, P., \& Shaad, K. Use of waste plastic aggregation in concrete as a constituent material. Progressive Agriculture, 27(3) (2016), 383-391.

[12.] Praveen Mathew, Shibi Varghese, Thomas Paul, Eldho Varghese. Recycled Plastics as Coarse Aggregate for Structural Concrete. International Journal of Innovative Research in Science, Engineering and Technology, 2 (3) (2013), 687-690.

[13.] ASTM C127-15. Standard Test Method for Relative Density (Specific Gravity) and Absorption of Coarse Aggregate, ASTM International, West Conshohocken, PA, (2015).

[14.] ASTM C128-15. Standard Test Method for Relative Density (Specific Gravity) and Absorption of Fine Aggregate, ASTM International, West Conshohocken, PA, (2015).

[15.] ASTM C136 / C136M-14. Standard Test Method for Sieve Analysis of Fine and Coarse Aggregates, ASTM International, West Conshohocken, PA, (2014).

[16.] ASTM C29 / C29M-97. Standard Test Method for Bulk Density ("Unit Weight") and Voids in Aggregate, ASTM International, West Conshohocken, PA, (1997).

[17.] ASTM C33/C33M-18. Standard Specification for Concrete Aggregates. American Society for Testing and Materials: West Conshohocken, PA, USA. (2018). www.astm.org

[18.] ASTM C109/C109M-20b. Standard Test Method for Compressive Strength of Hydraulic Cement Mortars (Using 2-in. or [50 mm] Cube Specimens). American Society for Testing and Materials: West Conshohocken, PA, USA. (2020). www.astm.org

[19.] ACI 211.1-91. Standard Practice for Selecting Proportions for Normal, Heavyweight, and Mass Concrete. American Concrete Institute. (1991).

[20.] ASTM C31 / C31M-19. Standard Practice for Making and Curing Concrete Test Specimens in the Field, ASTM International, West Conshohocken, PA, (2019).

[21.] ASTM C143 / C143M-15a. Standard Test Method for Slump of Hydraulic-Cement Concrete, ASTM International, West Conshohocken, PA, (2015).

[22.] ASTM C39 / C39M-14. Standard Test Method for Compressive Strength of Cylindrical Concrete Specimens, ASTM International, West Conshohocken, PA, (2014).

[23.] ASTM C125-10a. Standard Terminology Relating to Concrete and Concrete Aggregates.

[24.] C. Albano a, N. Camacho a, M. Hernández b, A. Matheus a, A. Gutiérrez a. Influence of content and particle size of waste pet bottles on concrete behavior at different w/c ratios, Waste Management, 29 (10) (2009), 2707-2716.

\section{How to Cite This Article}

Haque, M.R., Hossain, M.B., Roknuzzaman, M., Emu, N.A.A., and Jahan, F.T., Performance Of Partially Replaced Plastic Bottles (Pet) As Coarse Aggregate In Producing Green Concrete, Brilliant Engineering, 4(2021), 15-19. https://doi.org/10.36937/ben.2021.004.004 